\title{
COVID-19: Case fatality and ACE2 inhibitors treatment concerns in patients with comorbidities
}

\author{
Rokhsareh Aghili ${ }^{1}$, Maryam Honardoost*1,2 (D), Mohammad E Khamseh ${ }^{1}$
}

Received: 7 Jun $2020 \quad$ Published: 2 Nov 2020

\begin{abstract}
The Corona Virus Disease 2019 (COVID-19) outbreak is becoming pandemic with the highest mortality in patients with associated comorbidities. These RNA viruses containing 4 structural proteins usually use spike protein to enter the host cell. Angiotensinconverting enzyme 2 (ACE2) acts as a host receptor for the virus. Therefore, medications acting on renin-angiotensin-aldosterone system can lead to serious complications, especially in patients with diabetes and hypertension. To avoid this, other potential treatment modalities should be used in COVID-19 patients with associated comorbidities.
\end{abstract}

Keywords: COVID-19, Associated comorbidities, Treatment, ACE2 inhibitors, Type 2 diabetes

Conflicts of Interest: None declared

Funding: None

\section{*This work has been published underCC BY-NC-SA 1.0 license.}

Copyright $₫$ Iran University of Medical Sciences

Cite this article as: Aghili R, Honardoost M, Khamseh ME. COVID-19: Case fatality and ACE2 inhibitors treatment concerns in patients with comorbidities.Med J Islam Repub Iran. 2020(2 Nov);34:147. https://doi.org/10.47176/mjiri.34.147

\section{Introduction}

One of the major challenges in the $21^{\text {st }}$ century is the spread of emerging infectious diseases; namely, the ongoing new Coronavirus pneumonia (Corona Virus Disease 2019, COVID-19) outbreak. COVID-19 as the latest infectious disease has become a pandemic (1-3). Coronaviruses identified in the mid-1960s cause disease in humans and a variety of animals; SARS-CoV, and MERS$\mathrm{CoV}$ are 2 coronaviruses causing outbreaks in humans (4). Genetic analysis revealed COVID-19 is very similar to the severe acute respiratory syndrome (SARS) $(1,5)$. It genetically clusters within the genus betacoronavirus (4); however, discordant clustering with the Bat SARS-like coronavirus sequences has been detected (5). There is evidence that COVID-19 is not mosaic with a distinct lineage in almost half of its genome within the betacoronavirus (5).

Corresponding author: Dr Maryam Honardoost, honardoost.m@iums.ac.ir

1. Endocrine Research Center, Institute of Endocrinology and Metabolism, Iran University of Medical Sciences, Tehran, Iran

2. Cardio-Oncology Research Center, Rajaie Cardiovascular Medical \& Research Center, Iran University of Medical Sciences, Tehran, Iran
The last COVID-19 Situation Report of World Health Organization (WHO) on September 7, 2020, reported 27 million diagnosed cases with 900000 deaths worldwide (6).

The most prevalent comorbidity in the confirmed COVID-19 patients was hypertension, which was found in $1 / 5$ of the patients, consistent with the tendency of the virus binding with ACE2 receptor. Diabetes mellitus (DM) was detected in almost 10\%; other comorbidities such as chronic liver disease, kidney, heart, and even lung diseases were present in less than $10 \%$ of the patients $(7$, 8).

\section{COVID-19 infection and case fatality estimates}

WHO-China Joint Mission group reported that among

\section{$\uparrow$ What is "already known" in this topic:}

The Coronavirus uses ACE2 as a receptor to enter the cell; therefore, targeting ACE2 binding may prevent COVID-19 infection.

\section{$\rightarrow$ What this article adds:}

There is a negative impact on COVID-19-associated comorbidities; namely, diabetes and hypertension, which are treated with ACE2 inhibitor. The angiotensin AT1 receptors (AT1R) blockers are suggested to lower the rate of complications and mortality in COVID-19. Recombinant therapeutic approaches could be administrated against COVID19 particularly in presence of comorbid conditions. 
55924 laboratory confirmed cases, 2114 cases died since February 20, 2020 (Crude Fatality Ratio [CFR]: 3.8\%). Demographic factors, including age and sex, are risk factors for COVID-19 infection. The highest mortality is reported among patients over 80 years (CFR 21.9\%) and in men (4.7\% vs. $2.8 \%)(7-9)$. The lower risk in women could be justified by the plausible protective effect of the $\mathrm{X}$ chromosome and sex hormones having a significant contribution in innate and adaptive immunity (10). Furthermore, obesity and presence of comorbidity are associated with significant increase in mortality (10). The CFR is higher in the presence of hypertension (CFR: $8.4 \%$ ), diabetes (CFR: 9.2\%), cardiovascular disease (CFR: 13.2\%), chronic respiratory disease (CFR: $8 \%$ ), and cancer (CFR: 7\%). This could be explained by the weaker immune function $(9,10)$, while in patients without any comorbidity, the CFR was reported to be $1.4 \%$ (7-9).

In another report by Chinese Center for Disease Control and Prevention, the CFR was reported to be $0.9 \%$ among patients without comorbidity, while this figure was $10.5 \%$ for those with cardiovascular disease, $7.3 \%$ for diabetes, $6.3 \%$ for chronic respiratory disease, $6.0 \%$ for hypertension, and $5.6 \%$ for cancer (3).

Based on previous published data, the prevalence of important COVID-19 comorbid conditions is summarized in Table 1 . Chen et al found about $50 \%$ of patients infected with COVID-19 had a comorbidity, mainly cardiovascular/cerebrovascular diseases (40\%) and diabetes (12.12\%) (3).

Denget al reported that among 41 patients who had confirmed COVID-19, by January 2, 2020, a total of 30 $(73 \%)$ were men and less than $50 \%$ had underlying diseases $(13[32 \%])$ such as diabetes $(8[20 \%])$, hypertension (6 [15\%]), and cardiovascular disease (6 [15\%]), which shows underlying diseases are crucial factors resulting in the death of COVID-19 patients $(11,12)$.

In a study on 138 patients, 102 did not receive ICU care, while 36 patients required ICU care due to older age (median age, 66 years [IQR, 57-78] vs 51 years [IQR, 37-62]; $\mathrm{P}<0.001)$ and underlying diseases such as hypertension (21 [58.3\%] vs 22 [21.6\%], diabetes (8 [22.2\%] vs 6 $[5.9 \%])$, cardiovascular disease $(9[25.0 \%]$ vs 11 $[10.8 \%])$, and cerebrovascular disease $6[16.7 \%]$ vs 1 [1.0\%]) (13).

Several studies have reported $38.7 \%$ to $64.3 \%$ of diagnosed COVID-19 patients had at least one chronic medi- cal illness andthe most prevalent of which were diabetes and hypertension (Table 1) $(14,15)$.

\section{COVID-19 virus exploited host ACE2 receptor}

Coronaviruses are RNA viruses containing at least 4 structural proteins, including the membrane, envelope, spike, and nucleocapsid protein $(5,16)$. During virus infection, spike facilitates attachment to cellular receptor or attachment factors (17-19). Angiotensin-converting enzyme 2 (ACE2) as one of the membrane exopeptidase acts as a host receptor for COVID-19 to enter the human cells $(4,20)$. ACE2 as a part of renin-angiotensin-aldosterone system (RAAS) regulates vasoconstriction, sodium reabsorption, and electrolyte balance resulting in blood pressure control (18). Within the RAAS, angiotensin (Ang) I is converted into the vasoconstrictor Ang II by ACE, while ACE2 counterbalance the pathway with great affinity to Ang II and transform it to vasodilator Ang 1-7 (18).

Michael Letko et al demonstrated COVID-19 may enter the cell by expressing human ACE2, confirming the role of ACE2 in virus infection (16). High expression of ACE2 in oral cavity and specifically epithelial cells of tongue explains the reason for susceptibility of oral cavity for COVID-19 infection. ACE2 is also highly expressed in lung, esophagus, ileum, colon, cholangiocytes, myocardial cells, renal proximal tubule cells, and bladder urothelial cells, indicating these organs can be affected by COVID19 infection (21). However, its role in development of lung injury in SARS-Cov infection was controversial because of downregulation of ACE2 expression as infection initiated (14). It might have dual effects: as a receptor for virus entrance and as a lung injury promoter by downregulation (14).

Treatment modalities targeting host cell receptor and virus entry

No specific medication or vaccine has been made against COVID-19 yet (22). Two classes of medications are currently used to treat COVID-19: one targets human immune system and the other acts on the Coronavirus itself (19). Considering the potential routes of SARSCoV-2 entrance to the host cell, an effective therapeutic option can be based on the virus-host cell receptor interaction to inhibit the virus entry. The virus uses ACE2 as a receptor to enter the cell; therefore, targeting ACE2 binding may prevent COVID-19 infection $(4,21,23)$. Chloro-

Table 1.Prevalence of important comorbid conditions

\begin{tabular}{|c|c|c|c|c|c|c|}
\hline $\begin{array}{l}\text { Laboratory confirmed cases } \\
(\mathrm{N})\end{array}$ & $\begin{array}{c}\text { Cardiovascular disease } \\
\% \\
\end{array}$ & $\begin{array}{c}\text { Diabetes } \\
\% \\
\end{array}$ & $\begin{array}{c}\text { Hypertension } \\
\% \\
\end{array}$ & $\begin{array}{c}\text { Chronic respiratory } \\
\text { disease } \% \\
\end{array}$ & $\begin{array}{c}\text { Cancer } \\
\% \\
\end{array}$ & $\overline{\text { Ref }}$ \\
\hline 41 & 15 & 20 & 15 & - & - & $(10)$ \\
\hline 26 & 19.2 & 42.3 & 53.8 & 19.2 & - & (9) \\
\hline 138 & 14.5 & 10.1 & 31.2 & - & 7.2 & (11) \\
\hline 36 (ICU admitted) & 25 & 22.2 & 53.8 & - & - & (11) \\
\hline 102 & 10.8 & 5.9 & 21.6 & - & - & (11) \\
\hline 9 & - & 11.11 & - & - & - & (38) \\
\hline 140 & - & 12.1 & 30 & & - & (12) \\
\hline 1099 & 2.5 & 7.4 & 15 & 1.1 & 0.9 & (13) \\
\hline 926 (non severe) & 1.8 & 5.7 & 13.4 & 0.6 & 0.8 & (13) \\
\hline 173 (severe) & 5.8 & 16.12 & 23.7 & 3.5 & 1.7 & (13) \\
\hline 99 & 40 & 12.12 & - & - & 1 & (8) \\
\hline 44,672 & 4.2 & 5.3 & 12.8 & 2.4 & 0.5 & (3) \\
\hline
\end{tabular}


quine, an old drug used to treat malaria, amoebiasis, HIV, and autoimmune diseases has been effective in treatment of COVID-19 $(24,25)$. It acts via increasing endosomal $\mathrm{pH}$ required for viral entrance to the cell. Furthermore, it interferes with the glycosylation of ACE2 (impairment of terminal glycosylation), leading to less affinity between ACE2 and SARS-CoV spike protein and inability of the virus to attach to cell and thus preventing infection initiation (24).

On the other hand, an effective and safe approach is passive immunization (26). Monoclonal antibodies are the important class of medications in immunotherapy with higher specificity, purity, safety, and low risk of contamination compared to serum therapy and intravenous immu- noglobulins.

Considering the results of the study conducted by Khan et al on patients with ARDS, GSK2586881, a recombinant human ACE2 (rhACE2), resulted in a decrease in plasma Ang II and IL-6 and increase in Ang 1-7 $(27,28)$. Therefore, it could potentially be used for severe COVID-19. Viral/ host-targeted agents; their mechanism of action are summarized in Table 2.

\section{ACE2-based therapy: The link between infection sus- ceptibility and treatment controversially}

Under-glycosylation of ACE2by using chloroquine may prevent virus infection. On the other hand, it may interfere with the normal function of ACE2 and lead to cardiovas-

Table 2.Summary of potential antiviral agents against COVID-19 based on targeting virus-receptor binding and virus entry

\begin{tabular}{|c|c|c|c|}
\hline Infectious diseases & Antiviral agents & Reported mechanism of action & Action status \\
\hline $\begin{array}{l}\text { 2019-nCoV, } \\
\text { MERS-CoV }\end{array}$ & Nafamostat & Inhibits spike-mediated membrane fusion & $\begin{array}{l}\text { Approved for anticoagulant therapy in } \\
\text { Asian countries }\end{array}$ \\
\hline SARS-CoV & $\begin{array}{l}\text { Griffithsin } \\
\text { ( red-alga-derived } \\
\text { lectin) }\end{array}$ & $\begin{array}{l}\text { Inhibits viral entry. Docking results showed that } \\
\text { glycyrrhizin has the potential biding to ACE2. }\end{array}$ & $\begin{array}{l}\text { Phase I for the prevention of HIV } \\
\text { transmission }\end{array}$ \\
\hline SARS-CoV & $\begin{array}{l}\text { Glycyrrhizin } \\
\text { (liquorice root) }\end{array}$ & $\begin{array}{l}\text { Inhibits viral entry. Docking results showed that } \\
\text { glycyrrhizin has the potential biding to ACE2. }\end{array}$ & $\begin{array}{l}\text { Clinical trials for treatment of liver } \\
\text { diseases [63] }\end{array}$ \\
\hline $\begin{array}{l}\text { SARS-CoV, } \\
\text { MERS-CoV, } \\
\text { Influenza }\end{array}$ & Peptide (P9) & $\begin{array}{l}\text { Inhibits spike protein-mediated } \\
\text { cell-cell entry or fusion }\end{array}$ & Preclinical \\
\hline $\begin{array}{l}\text { HCoV (e.g. } \\
\text { MERS, SARS }\end{array}$ & $\begin{array}{l}\text { OC43-HR2P (most } \\
\text { promising EK1) }\end{array}$ & Inhibits pan-CoV fusion & Preclinical \\
\hline HCoV-229E & $\begin{array}{l}\text { 229E-HR1P } \\
\text { 229E-HR2P }\end{array}$ & $\begin{array}{l}\text { Inhibits spike protein-mediated } \\
\text { cell-cell fusion }\end{array}$ & Preclinical \\
\hline $\begin{array}{l}\mathrm{HCoV} \text {, Influenza } \\
\text { virus }\end{array}$ & $\begin{array}{l}\text { 1-thia-4-azaspiro } \\
\text { [4.5] decan-3-one } \\
\text { derivatives } \\
\text { (Compound } 8 \mathrm{n} \text { ) }\end{array}$ & - & Preclinical \\
\hline $\begin{array}{l}2019-\mathrm{nCoV} \\
\text { SARS-CoV } \\
\text { MERS-CoV }\end{array}$ & Chloroquine & $\begin{array}{l}\text { Elevates the endosomal } \mathrm{pH} \text {, and appears to inter- } \\
\text { fere with terminal glycosylation of ACE2. Thus } \\
\text { affects the viral fusion and trafficking events. }\end{array}$ & $\begin{array}{l}\text { Approved for malaria and certain } \\
\text { amoeba infections Open-label trial for } \\
\text { 2019-nCoV (ChiCTR2000029609) }\end{array}$ \\
\hline $\begin{array}{l}\text { SARS-CoV } \\
2019-\mathrm{nCoV}\end{array}$ & SSAA09E2 & $\begin{array}{l}\text { Blocks early interactions of SARS-S with the re- } \\
\text { ceptor for ACE2 }\end{array}$ & Preclinical \\
\hline $\begin{array}{l}\text { SARS-CoV } \\
\text { 2019-nCoV }\end{array}$ & SSAA09E3 & $\begin{array}{l}\text { Prevents fusion of the viral membrane with the host } \\
\text { cellular membrane }\end{array}$ & Preclinical \\
\hline $\begin{array}{l}\text { SARS-CoV } \\
\text { 2019-nCoV }\end{array}$ & NAAE & $\begin{array}{l}\text { Inhibits both ACE2 catalytic activity and S-protein- } \\
\text { induced cell-cell fusion }\end{array}$ & Preclinical \\
\hline SARS-CoV-2 & TMPRSS2 inhibitor & $\begin{array}{l}\text { Inhibits viral S protein cleavage and does not } \\
\text { allow the fusion of viral and cellular membranes }\end{array}$ & $\begin{array}{l}\text { The protease inhibitor camostat mesyl- } \\
\text { ate, which blocks TMPRSS2 activity } \\
\text { has been approved in Japan for human } \\
\text { use, but for an unrelated indication. }\end{array}$ \\
\hline Coronavirus & R80-GSK2586881 & $\begin{array}{c}\text { Recombinant human ACE2 which resulted in a } \\
\text { rapid decrease in plasma Ang II levels and increase } \\
\text { in Ang 1-7 levels }\end{array}$ & $\begin{array}{l}\text { Phase II trial examining the safety and } \\
\text { efficacy in patients with ARDS. }\end{array}$ \\
\hline
\end{tabular}



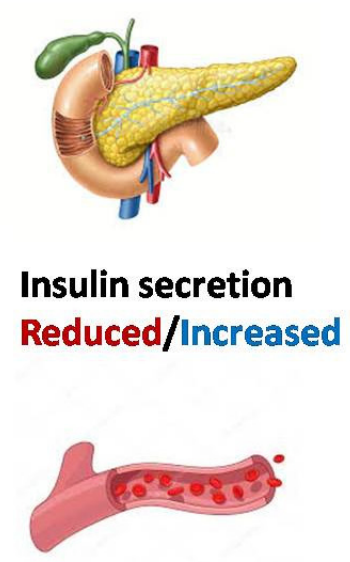

Blood pressure Reduced/Increased
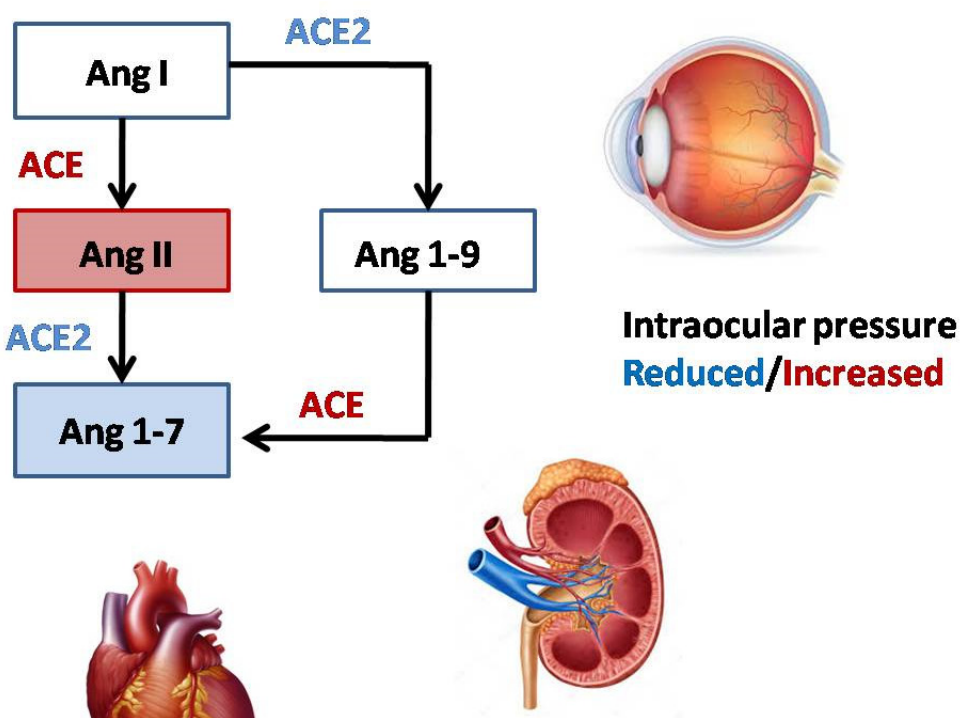

\section{Glomerular filtration rate Reduced/Potentially improved}

\section{Cardiomyopathy Reduced/Increased}

Fig. 1.RAAS and ACE/ACE 2 effects on T2D and associated complications

cular complications $(29,30)$. ACE2 dysfunction results in elevated concentration of Ang II, which increases oxidative stress and inflammation and could lead to development of metabolic syndrome, diabetes, and diabetesrelated complications (29). ACE2/Ang(1-7) pathway has the protective effect in patients with type 2 diabetes and can be a treatment strategy in Ang-II-mediated T2DM through modulating blood glucose by adjusting the levels of Ang II and/or Ang-(1-7) in pancreatic cells and regulating insulin secretion (31-33) (Fig. 1).

Diabetic cardiomyopathy: Cardiovascular disease is highly prevalent in patients with diabetes compared to the general population. RAAS activation and imbalance in ACE-Ang II and ACE2-Ang 1-7 are highly accused in this process (18). High blood glucose can promote local Ang II production in heart tissue. RAAS is also upregulated in diabetes and can lead to activation of AngII pathway and subsequently inflammation, increased oxidative stress, cell proliferation, apoptosis, and fibrosis, which contribute to cardiac remodeling and atherosclerosis. However, ACE2 improves cardiac function by preventing myocardial fibrosis, reducing remodeling, and developing left ventricular hypertrophy and pressure-overload-induced heart failure (23). Therefore, RAAS inhibition by ACE inhibitors and angiotensin II receptor blockers has been recommended as the first line therapy in CVD in patients with diabetes by lowering target-organ damages well as controlling blood pressure $(18,23)$ (Fig. 1).

Diabetes and hypertension:ACE2 is also present in endothelium of blood vessels; therefore, its reduction could result in increased Ang II level and contribute to elevated blood pressure (34). In a study on rats, overexpression of ACE2 in the blood vessels improved endothelial function leading to reduced blood pressure, while ACE2 deficiency could contribute to increased systolic blood pressure (34, 35). Furthermore, central hypertension can be affected by the level of ACE2 (35). Therefore, ACE2 replenishing may be a significant therapeutic approach against diabetic hypertension.

Diabetic nephropathy: Diabetic nephropathy is a microvascular diabetes-related complication associated with CVD risk in patients with diabetes. Normally, ACE2 is expressed in the kidney predominantly at the luminal brush border of the proximal tubule, while in patients with diabetic nephropathy as well as other forms of chronic kidney disease, ACE2 expression may downregulate and result in albuminuria or tubular injury. Therefore, further renal injury will occur with more ACE2 inhibition (35). In a study conducted by Harris et al, the ACE/ACE2 ratio was found to be increased in both glomerulus and tubulointerstitium of patients with diabetic nephropathy, which is mostly due to reduced ACE2 expression (36). Another study on diabetic mice showed total ACE2 reduction/deletion and pharmacologic ACE2 inhibition may result in diabetic nephropathy (31). However, ACE2 can reduce the progression of diabetic nephropathy by direct effect on glomerulus (36) (Fig. 1).

Diabetic Retinopathy: The most prevalent microvascular diabetes-related complication is diabetic retinopathy (DR) in which abnormal activity of the RAAS has an essential role (29). In contrast, overexpression of ACE2/Ang-(1-7) may have a protective role against DR 
(37). Animal studies revealed ACE2 as the counterregulator of Ang II can reduce the intraocular pressure in addition to inflammatory process $(29,38)$. In line with the results, treatment with recombinant ACE2 could decrease inflammatory process, reduce acellular capillaries, and prevent retinal ganglion cell loss (38). Therefore, it seems increasing the bioavailability of ACE2 has a critical role in treating diabetes-related complications (38) (Fig. 1).

\section{Conclusion}

The occurrence and development of COVID-19 infection depends on viral factors and host individual factors, including genetics, age, gender, nutrition, and health status (39-41).

Patients with associated comorbidities comprise a highrisk group for Coronavirus infection. The morbidity and mortality are higher in this high-risk patients compared to healthy individuals.

COVID-19 entry to the host cell depends on ACE2 receptor; therefore, a potential treatment strategy for COVID-19 could be inhibiting the ACE2 receptor. However, this may have a negative impact on associated comorbidities such as diabetes and hypertension that are treated with ACE inhibitor (42) because of the protective effect of ACE2/Ang(1-7) pathway in patients with type 2 diabetes as well as treatment strategies in Ang-II-mediated T2DM (31-33). In addition, ACEIs upregulate ACE2, which can accelerate viral uptake and colonization in the host's cells (43). Viral attachment to ACE2 via the spike protein results in ACE2 downregulation and excessive production of Ang II and lower level of Ang 1-7, which in turn leads to lung damage through Angiotensin II receptor type I (AT1R) stimulation (22).Increased RAS activity with enhanced AT1R stimulation is a major injury factor affecting the cardiovascular and renal function, lipid and glucose metabolism, the immune system, and more to the point, inflammatory lung disease. AT1R blocking directly reduces inflammation, organ fibrosis and endothelial injury, protects mitochondrial function, maintains insulin sensitivity and energy metabolism, protects lipid metabolism and normalizes the coagulation cascade; these properties are considered to benefit patients with acute critical disorders (44). Therefore, AT1R blockers are suggested to lower the rate of complications and mortality in COVID19 (22).

Moreover, there are many other therapeutic approaches, such as recombinant soluble ACE2, with less complications mainly in presence of comorbid conditions. Overall, serious efforts must be made to choose an effective treatment for COVID-19 infection, particularly in patients with diabetes.

\section{Conflict of Interests}

The authors declare that they have no competing interests.

\section{References}

1. Chen Z, Zhang Q, Lu Y, Guo Z, Zhang X, Zhang W, et al. Distribution of the COVID-19 epidemic and correlation with population emigration from wuhan, China. Chin Med J. 2020.
2. Boldog P, Tekeli T, Vizi Z, Dénes A, Bartha FA, Röst G. Risk assessment of novel coronavirus COVID-19 outbreaks outside China. J Clin Med. 2020;9(2):571.

3. Honardoost M, Janani L, Aghili R, Emami Z, Khamseh ME. The Association Between Presence of Comorbidities and COVID-19 Severity; A Systematic Review and Meta-Analysis. prerrint. 2020.

4. de Wit E, van Doremalen N, Falzarano D, Munster VJ. SARS and MERS: recent insights into emerging coronaviruses. Nature Reviews Microbiology. 2016;14(8):523.

5. Paraskevis D, Kostaki EG, Magiorkinis G, Panayiotakopoulos G, Sourvinos G, Tsiodras S. Full-genome evolutionary analysis of the novel corona virus $(2019-\mathrm{nCoV})$ rejects the hypothesis of emergence as a result of a recent recombination event. Infect Genet Evol. 2020;79:104212.

6. Coronavirus disease (COVID-19) Weekly Epidemiological Update. https://www.who.int/docs/default-source/coronaviruse/situationreports/20200907-weekly-epi-update-4.pdf?sfvrsn=f5f607ee_2

7. Baradaran A, Ebrahimzadeh $\mathrm{MH}$, Baradaran A, Kachooei AR Prevalence of Comorbidities in COVID-19 Patients: A Systematic Review and Meta-Analysis. Arch Bone Jt Surg. 2020;8(Covid-19 Special Issue:247-255

8. Ghavideldarestani M, Honardoost M, Khamseh ME. Role of Vitamin D in Pathogenesis and Severity of COVID-19 Infection. Arch Physiol Biochem. Inpress. 2020.

9. Report of the WHO-China Joint Mission on Coronavirus Disease 2019 (COVID-19) 16- 24 February $2020 \mathrm{https} / /$ wwwwhoint/docs/defaultsource/coronaviruse/who-china-joint-mission-on-covid-19-finalreportpdf.

10.Chen N, Zhou M, Dong $\mathrm{X}$, Qu J, Gong $\mathrm{F}$, Han $\mathrm{Y}$, et al Epidemiological and clinical characteristics of 99 cases of 2019 novel coronavirus pneumonia in Wuhan, China: a descriptive study. Lancet. 2020;395(10223):507-13

11.Deng SQ, Peng HJ. Characteristics of and Public Health Responses to the Coronavirus Disease 2019 Outbreak in China. J Clin.Med. 2020;9(2):575.

12.Huang C, Wang Y, Li X, Ren L, Zhao J, Hu Y, et al. Clinical features of patients infected with 2019 novel coronavirus in Wuhan, China. Lancet. 2020;395(10223):497-506.

13.Wang $\mathrm{D}, \mathrm{Hu} \mathrm{B}, \mathrm{Hu} \mathrm{C}$, Zhu F, Liu X, Zhang J, et al. Clinical characteristics of 138 hospitalized patients with 2019 novel coronavirus-infected pneumonia in Wuhan, China. JAMA. 2020.

14.Zhang Jj, Dong X, Cao YY, Yuan Yd, Yang Yb, Yan Yq, et al. Clinical characteristics of 140 patients infected by SARS-CoV-2 in Wuhan, China. Allergy. 2020

15.Guan WJ, Ni ZY, Hu Y, Liang WH, Ou CQ, He JX, et al. Clinical characteristics of coronavirus disease 2019 in China. N Engl J Med. 2020;382:1708-1720

16.Letko MC, Munster V. Functional assessment of cell entry and receptor usage for lineage B $\beta$-coronaviruses, including 2019-nCoV. bioRxiv. 2020 .

17.Adedeji AO, Severson W, Jonsson C, Singh K, Weiss SR, Sarafianos SG. Novel inhibitors of severe acute respiratory syndrome coronavirus entry that act by three distinct mechanisms. J Virol. 2013;87(14):801728

18.Bernardi S, Michelli A, Zuolo G, Candido R, Fabris B. Update on RAAS modulation for the treatment of diabetic cardiovascular disease. J Diabetes Res. 2016;2016.

19.Li G, De Clercq E. Therapeutic options for the 2019 novel coronavirus (2019-nCoV). Nature Publishing Group; 2020.

20.Hoffmann M, Kleine-Weber H, Schroeder S, Krüger N, Herrler T, Erichsen S, et al. SARS-CoV-2 Cell Entry Depends on ACE2 and TMPRSS2 and Is Blocked by a Clinically Proven Protease Inhibitor. Cell. 2020.

21.Xu H, Zhong L, Deng J, Peng J, Dan H, Zeng X, et al. High expression of ACE2 receptor of 2019-nCoV on the epithelial cells of oral mucosa Int J Oral Sci. 2020;12(1):1-5.

22.Gurwitz D. Angiotensin receptor blockers as tentative SARS-CoV-2 therapeutics. Drug Dev Res. 2020. Aug;81(5):537-540.

23.Wang J, He W, Guo L, Zhang Y, Li H, Han S, et al. The ACE2-Ang (1-7)-Mas receptor axis attenuates cardiac remodeling and fibrosis in post-myocardial infarction. Mol Med Rep. 2017;16(2):1973-81.

24.Vincent MJ, Bergeron E, Benjannet S, Erickson BR, Rollin PE, Ksiazek TG, et al. Chloroquine is a potent inhibitor of SARS coronavirus infection and spread. Virol J. 2005;2(1):69.

25.Cortegiani A, Ingoglia G, Ippolito M, Giarratano A, Einav S. A 
systematic review on the efficacy and safety of chloroquine for the treatment of COVID-19. J Crit Care. 2020;57:279-283.

26.Sui J, Li W, Murakami A, Tamin A, Matthews LJ, Wong SK, et al. Potent neutralization of severe acute respiratory syndrome (SARS) coronavirus by a human $\mathrm{mAb}$ to $\mathrm{S} 1$ protein that blocks receptor association. Proc Natl Acad Sci. 2004;101(8):2536-41.

27.Li Y, Chen M, Cao H, Zhu Y, Zheng J, Zhou H. Extraordinary GU-rich single-strand RNA identified from SARS coronavirus contributes an excessive innate immune response. Microb Infect. 2013;15(2):88-95.

28.Zhang H, Baker A. Recombinant human ACE2: acing out angiotensin II in ARDS therapy. Springer; 2017.

29.Foureaux G, Nogueira B, Coutinho D, Raizada M, Nogueira J, Ferreira A. Activation of endogenous angiotensin converting enzyme 2 prevents early injuries induced by hyperglycemia in rat retina. Braz J Med Biol Res. 2015;48(12):1109-14.

30.Yan R, Zhang Y, Li Y, Xia L, Guo Y, Zhou Q. Structural basis for the recognition of the SARS-CoV-2 by full-length human ACE2. Science. 2020.

31.Batlle D, Soler MJ, Ye M. ACE2 and diabetes: ACE of ACEs? Diabetes. 2010;59(12):2994-6.

32.Chhabra KH, Chodavarapu H, Lazartigues E. Angiotensin converting enzyme 2: a new important player in the regulation of glycemia. IUBMB Life. 2013;65(9):731-8.

33.Bindom SM, Hans CP, Xia H, Boulares AH, Lazartigues E. Angiotensin I-converting enzyme type 2 (ACE2) gene therapy improves glycemic control in diabetic mice. Diabetes. 2010;59(10):2540-8.

34.Chamsi-Pasha MA, Shao Z, Tang WW. Angiotensin-converting enzyme 2 as a therapeutic target for heart failure. Curr Heart Fail Rep 2014;11(1):58-63.

35.Tikellis C, Thomas M. Angiotensin-converting enzyme 2 (ACE2) is a key modulator of the renin angiotensin system in health and disease. Int J Pept. 2012;2012.

36. Harris RC. Podocyte ACE2 protects against diabetic nephropathy. Kidney Int. 2012;82(3):255-6.

37.Verma A, Shan Z, Lei B, Yuan L, Liu X, Nakagawa T, et al. ACE2 and Ang-(1-7) confer protection against development of diabetic retinopathy. Mol Ther. 2012;20(1):28-36.

38.Verma A, Xu K, Du T, Zhu P, Liang Z, Liao S, et al. Expression of human ACE2 in Lactobacillus and beneficial effects in diabetic retinopathy in mice. Mol Ther Methods Clin Dev 2019;14:161-70.

39.Qiu R, Wei X, Zhao M, Zhong C, Zhao C, Hu J, et al. Outcome reporting from protocols of clinical trials of Coronavirus Disease 2019 (COVID-19): a review. medRxiv. 2020.

40.Wang C, Horby PW, Hayden FG, Gao GF. A novel coronavirus outbreak of global health concern. Lancet. 2020;395(10223):470-3.

41.Zhang M, Wang X, Chen Y, Zhao K, Cai Y, An C, et al. Clinical features of 2019 novel coronavirus pneumonia in the early stage from a fever clinic in Beijing. Chinese J Tuberculos Respir Dis. 2020;43:E013.

42.Estacio RO, Jeffers BW, Hiatt WR, Biggerstaff SL, Gifford N, Schrier RW. The effect of nisoldipine as compared with enalapril on cardiovascular outcomes in patients with non-insulin-dependent diabetes and hypertension. N Engl J Med. 1998;338(10):645-52.

43.Huang Ml, Li X, Meng Y, Xiao B, Ma Q, Ying Ss, et al. Upregulation of angiotensin-converting enzyme (ACE) 2 in hepatic fibrosis by ACE inhibitors. Clin Exp Pharmacol Physiol. 2010;37(1):e1-e6.

44.Saavedra JM. Angiotensin Receptor Blockers and 2019-nCoV. Pharmacol Res. 2020:104832. 